\title{
WACANA PENYINTAS KEKERASAN SEKSUAL DALAM PERSPEKTIF KRITIS TIRTO.ID
}

\author{
Suprihatin, Rizky Nindy Lestari \\ Program Studi Ilmu Komunikasi \\ Sekolah Tinggi Ilmu Komunikasi-Almamater Wartawan Surabaya \\ JL, Nginden Intan Timur I No.18, Ngenden Jangkungan, Sukolilo, Surabaya, \\ Jawa Timur, 60118 \\ meetitien@gmail.com
}

\begin{abstract}
The issue of violence against women can be found in abundance within the mass media news. Quoting the Indonesia's National Committee on Violence Against Women (National Committee of Women) in 2017, there were 348,446 cases of violence against women. The data from National Committee of Women shows that there is a high percentage of sexual abuse within the domain of domestic or personal violence as well as community and public violence. The volume of news related to sexual abuses have been rising ever since the Police-General Tito Karnavian gave a controversial statement in October of 2017. As quoted from BBC Indonesia in an exclusive interview with Tito Karnavian, Tito said that in cases of rape accusations, the police sometimes must ask if the victim feels comfortable. This statement sparked a reaction from the public. Women activists highlighted Tito's statement and consider the questions to be insensitive because they ignore victims' psychological condition. Online news portal Titro.id actively discuss the development of Tito's controversial statement. Not only does Tirto.id presents the news on the subject matter, they also conduct deep investigations involving both parties: the police force and the survivors of sexual abuses. Tirto.id was also present in a funding night to support the work of sexual abuse survivors in 11 November 2017 in Kantor Dagang Serikat Islam, Central Jakarta. The report was written by a journalist of Tirto.id in the "In Depth" rubric or exhaustive reports in the form of information gathered from attending the event. In order to research this topic, the researcher used the critical discourse analysis technique. This research will be analyzed using Norman Fairclough's scalpel. The outcome of this research shows that, within the textual analysis, both lexically and grammatically, Tirto.id uses dictions that imply supportive attitude towards the victims and survivors of sexual abuse, for example, the use of "tegas" or "firm". Tirto.id also chooses negative adjectives such as "bereaksi keras" ("reacted violently") and "perilaku kasar bahkan kejam" ("violent or even cruel behavior") to be associated with the perpetrators of sexual violence. The use of active sentences indicates that Tirto.id reinforces the presence of actors of sexual violence from the text. Which often media ignored when reported of sexual violence.
\end{abstract}

Keywords: Critical Discourse Analysis, Norman Fairclough, news, sexual abuse.

\begin{abstract}
Abstrak
Isu tindak kekerasan terhadap perempuan merupakan peristiwa yang sering dijumpai dalam pemberitaan di media massa. Mengutip catatan Komnas Anti Kekerasan Terhadap Perempuan (Komnas Perempuan) tahun 2017, kasus kekerasan terhadap perempuan (KtP) sebesar
\end{abstract}


348.446. Data Komnas Perempuan menunjukkan kasus kekerasan seksual di ranah kekerasan dalam rumah tangga atau ranah personal (KDRT/RP) dan ranah komunitas dan publik memiliki persentase yang tinggi. Pemberitaan terkait kekerasan seksual makin ramai diperbincangkan ketika Kepala Kepolisian Republik Indonesia, Jenderal Tito Karnavian memberikan pernyataan yang kontroversial pada Oktober 2017. Dilansir dari BBC Indonesia, dalam wawancara ekslusifnya, Tito menyatakan bahwa dalam kasus pemerkosaan terkadang polisi harus bertanya apakah korban nyaman atau tidak. Pernyataan ini menimbulkan reaksi masyarakat. Aktivis perempuan menyoroti pernyataan Tito dan menganggap pertanyaan yang diajukan pada korban pemerkosaan tidak sensitif karena mengabaikan psikologis korban. Portal berita daring Tirto.id aktif mengulas perkembangan berita terkait pernyataan kontroversial Tito Karnavian. Tirto.id tidak hanya menayangkan berita terkait pernyataan tersebut, tetapi juga melakukan investigasi mendalam dengan melibatkan kedua pihak, yaitu kepolisian dan korban atau penyintas kekerasan seksual. Tirto.id turut hadir pada acara malam dana untuk mendukung karya penyintas kekerasan seksual pada 11 November 2017 di Kantor Dagang Serikat Islam, Jakarta Pusat. Laporan itu dituangkan jurnalis Tirto.id dalam rubrik In Depth atau laporan mendalam berupa informasi yang didapat selama mengikuti acara tersebut. Untuk meneliti topik ini, peneliti menggunakan teknik analisis wacana kritis. Penelitian ini akan dianalisis dengan menggunakan pisau bedah model Norman Fairclough. Hasil penelitian ini menunjukkan, dalam analisis tekstual secara leksikal dan gramatikal, Tirto.id memilih kosakata yang bernuansa suportif terhadap korban dan penyintas kekerasan seksual, seperti penggunaan kata "tegas" serta memilih kosakata yang berkonotasi negatif seperti "bereaksi keras" dan "perilaku kasar bahkan kejam" yang diasosiasikan pada pelaku tindak kekerasan seksual. Penggunaan kalimat aktif menunjukkan Tirto.id mempertegas kehadiran aktor kekerasan seksual dari teks, satu hal yang kerap diabaikan oleh media dalam peliputan berita tentang peristiwa kekerasan seksual.

Kata kunci: Analisis wacana kritis, Norman Fairclough, berita, kekerasan seksual.

\section{PENDAHULUAN}

Isu tindak kekerasan terhadap perempuan merupakan peristiwa yang sering dijumpai dalam pemberitaan di media massa. Mengutip catatan Komnas Anti Kekerasan Terhadap Perempuan (Komnas Perempuan) tahun 2017, kasus kekerasan terhadap perempuan (KtP) mencapai angka sebesar 348.446. Berdasarkan data tersebut, jenis kekerasan yang paling menonjol adalah kekerasan dalam rumah tangga/ranah personal (KDRT/RP) yang mencapai angka 71\% (9.609). Pada peringkat kedua, KtP terjadi di ranah komunitas atau publik. Persentasenya mencapai angka 26\% (3.528). Sedangkan di ranah negara, tingkat KtP mencapai 1,8\% (217).
Pada ranah KDRT/RP kekerasan yang paling menonjol adalah kekerasan fisik. Yakni sebanyak 3.982 kasus (41\%), kemudian kekerasan seksual sebanyak 2.979 kasus (31\%), kekerasan psikis sebanyak 1.404 kasus (15\%), dan kekerasan ekonomi sebanyak 1.244 kasus $(13 \%)$.

Pada ranah publik dan komunitas, sebanyak $76 \%$ kekerasan terhadap perempuan yang terjadi merupakan kekerasan seksual berupa pencabulan (911 kasus), pelecehan seksual (704 kasus), perkosaan (699 kasus), dan persetubuhan (343 kasus). Data Komnas Perempuan juga mencatat berbagai macam spektrum kekerasan terhadap perempuan. KtP tidak hanya terjadi di dunia nyata tetapi pelaku kekerasan juga menyasar perempuan- 
perempuan di dunia maya. Kekerasan ini berupa penghakiman digital bernuansa seksual, penyiksaan seksual, persekusi daring dan luring, maraknya situs dan aplikasi prostitusi daring berkedok agama, ancaman kriminalisasi perempuan dengan menggunakan UU ITE, kerentanan eksploitasi seksual anak perempuan dan eksploitasi tubuh perempuan di dunia maya, hingga yang terakhir kasus 'revenge porn' atau balas dendam dengan ancaman menyebarkan foto/video korban di media sosial.

Dari data-data tersebut dapat dilihat bahwa kasus kekerasan seksual di dua ranah, yaitu ranah KDRT/RP dan ranah komunitas dan publik, memiliki angka persentase yang tinggi. Kekerasan seksual bahkan menyasar anak-anak di bawah umur. Lembaga Perlindungan Saksi dan Korban (LPSK) mencatat kenaikan angka kasus kekerasan seksual terhadap anak pada 2017. Di tahun 2017, ada 111 permohonan perlindungan terhadap korban kekerasan seksual terhadap anak.

Pada Mei 2017 lalu, marak diberitakan kekerasan seksual yang dilakukan oleh penjaga sekolah sebuah TK di Bogor, Jawa Barat terhadap seorang siswi berusia empat tahun. Agustus 2017 muncul berita pelecehan seksual terhadap murid SD di Makassar, Sulawesi Selatan, yang dilakukan oleh oknum Kepala Sekolah.

Pemberitaan terkait kekerasan seksual semakin ramai diperbincangkan ketika Kepala Polri Jenderal Tito Karnavian memberikan pernyataan yang kontroversial pada Oktober 2017. Dilansir dari BBC Indonesia, dalam wawancara ekslusifnya Kapolri Jenderal Tito Karnavian menyatakan bahwa dalam kasus pemerkosaan, terkadang polisi harus bertanya tentang kenyamanan korban.
Pernyataan Kapolri menimbulkan reaksi masyarakat. Aktivis perempuan menyoroti pernyataan Tito dan menganggap pertanyaan yang diajukan pada korban pemerkosaan tidak sensitif karena mengabaikan psikolog is korban.

Penanganan korban kekerasan seksual oleh kepolisian ditangani oleh subunit Pelayanan Perempuan dan Anak (PPA). Dalam menangani korban perkosaan, unit PPA memiliki dua polisi wanita sebagai penyidik pembantu. Proses pemeriksaan pertama dilakukan melalui metode wawancara. Jika korban sudah siap menjalani proses pemeriksaan secara menyeluruh, korban akan diberi surat pengantar untuk melakukan visum kemudian menjawab pertanyaanpertanyaan pada Berita Acara Pemeriksaan (BAP).

Salah satu pertanyaan dalam BAP yang dinilai para aktivis perempuan tidak sensitif terhadap korban adalah poin ketujuh, yang berbunyi: “Apa yang saudari rasakan saat saudari disetubuhi oleh terlapor? Jelaskan!”

Di bawah pertanyaan itu, tersedia kolom untuk jawaban yang diisi korban. Menurut Bripka Imam Syaifudin, penyidik dari reserse kriminal yang menangani sub unit PPA di Polsek Pesanggrahan Jakarta Selatan, pertanyaan itu harus diajukan untuk keperluan analisis polisi. Namun, ada kompleksitas lain dalam melakukan penyidikan terhadap korban pemerkosaan. Jika aktivitas seksual terjadi karena hasil bujuk rayu pelauk, maka polisi akan kesulitan untuk menyimpulkan kasus tersebut sebagai perkosaan karena kurang bukti yang cukup. Pada kasus seperti itu, polisi biasanya memakai pasal persetubuhan. Bila kasus ini terjadi pada orang dewasa di atas 18 tahun, pelaku bisa bebas. Kecuali salah satu atau kedua orang 
tersebut terikat dalam perkawinan yang bisa diusut pasal zina sepanjang ada pengaduan dari pasangan resmi.

Selain itu, pada poin kesembilan dalam pertanyaan BAP berbunyi: "Apakah saudari menikmati berhubungan seks atau tidak?"

Pertanyaan tersebut juga dinilai tidak sensitif terhadap korban. Namun, Kanit V PPA Polres Metro Jakarta Selatan Nunu Suparmi mengatakan, pertanyaan ini ditujukan untuk mengetahui apakah ada unsur persetujuan (consent) atau tidak dalam kejadian tersebut. Pertanyaanpertanyaan bernuansa tidak sensitif lainnya juga tertuang dalam BAP penyidikan korban pemerkosaan seperti pertanyaan tentang detail posisi saat berhubungan seks hingga detail kronologi kejadian.

Sebagai publik figur, pernyataan yang dikeluarkan oleh Kapolri Jenderal Tito Karnavian kepada awak media memicu kontroversi. Pernyataan tersebut terekam dalam jejak digital media dan tidak dapat ditarik kembali. Hal ini dapat menggiring opini publik bahwa penyidik kepolisian abai terhadap psikologis korban. Pernyataan tersebut juga dapat menimbulkan sikap bebal pada khalayak terhadap kondisi dan rasa trauma korban kekerasan seksual.

Portal berita daring Tirto.id aktif mengulas perkembangan berita terkait pernyataan kontroversial Tito Karnavian. Tirto.id tidak hanya menayangkan berita terkait pernyataan tersebut, tetapi juga melakukan investigasi mendalam dengan melibatkan kedua pihak, yaitu kepolisian dan korban atau penyintas kekerasan seksual.

Tirto.id turut hadir pada acara malam dana untuk mendukung karya penyintas kekerasan seksual pada 11 November 2017 di Kantor Dagang Serikat
Islam, Jakarta Pusat. Laporan itu dituangkan jurnalis Tirto.id dalam rubrik In Depth atau laporan mendalam berupa informasi yang didapat selama mengikuti acara tersebut.

Berita, menurut Mitchell V. Charnley dalam Kusumaningrat (2007) adalah sebuah laporan tentang suatu peristiwa, opini, kecenderungan, situasi, kondisi, interpretasi yang penting, menarik, masih baru, dan harus secepatnya disampaikan pada khalayak. Dari definisi tersebut, dapat disimpulkan bahwa sebuah berita tidak selalu berisi fakta, tetapi bisa juga berupa opini wartawan yang menulis berita.

Meski beberapa teori jurnalistik menyebutkan bahwa, wartawan diharapkan tidak mencampuradukkan fakta dan opini pribadi dalam sebuah berita. Namun realitanya, wartawan bukanlah satusatunya pihak yang memegang kendali dalam penulisan berita. Wartawan yang bernaung dalam sebuah media tentu harus mematuhi peraturan penulisan berita yang diterapkan oleh media tersebut.

Dalam proses penulisan berita di sebuah media, ideologi dan nilai-nilai yang dianut oleh media tersebut dapat memengaruhi isi teks berita. Media tidak lagi menjadi pilar keempat demokrasi yang mengontrol fungsi trias politik, tetapi dapat menjadi pembentuk opini publik demi kepentingan-kepentingan tertentu.

Setiyaningsih (2019), dalam studinya kecepatan media online dalam menyampaikan informasi menjadi komodifikasi bagi waktu luang audiens. Hal ini terlihat dari hasil penelitian dimana media online whatsapp mampu menjadikan waktu luang ibu rumah tangga sebagai komodifikasi. Jika berbicara tentang komodifikasi, pembentukan opini publik menjadi sangat mudah dan terarah. Hal ini 
dikarenakan sumber informasi berpusat dan menyebar dengan cepat.

Pembentukan opini publik yang dilakukan oleh media massa dapat dilihat dari pemilihan diksi dan simbol pada artikel beritanya. Penggunaan kata, kalimat, istilah, dan simbol diasosiasikan pada makna tertentu. Penelitian ini akan berfokus pada bagaimana Tirto.id mengonstruksi pemberitaan mengenai penyintas kekerasan seksual dalam perspektif wacana kritis.

Menurut Eriyanto (2001), analisis wacana kritis adalah salah satu alternatif dari analisis isi selain analisis kuantitatif. Jika analisis kuantitatif lebih menekankan pada pernyataan 'apa', maka analisis wacana lebih menekankan pada 'bagaimana' dari pesan atau teks komunikasi. Analisis wacana tidak hanya melihat bagaimana isi teks berita, tetapi juga bagaimana pesan tersebut disampaikan.

Analisis wacana adalah kajian terhadap satuan bahasa di atas kalimat. Perluasan istilah ini dikaitkan dengan bagaimana konteks memengaruhi makna kalimat (Darma, 2014). Hal inilah yang mendorong peneliti untuk menggunakan analisis wacana dengan pendekatan paradigma kritis untuk melihat bagaimana Tirto.id menyusun informasi pada laporan mendalam berjudul "Kisah Korban Perkosaan yang Tak Akan Diindahkan Polisi".

Penelitian ini dilakukan dengan menggunakan pisau bedah model Norman Fairclough. Pendekatan Fairclough didasarkan pada wacana dan perubahan sosial (Darma, 2014). Dalam analisis wacana, Fairclough membagi dalam tiga dimensi, yaitu: Tekstual, teks dianalisis secara linguistik (tuturan, pencitraan visual, atau gabungan keduanya);
Discourse Practice, melibatkan proses produksi dan pengonsumsian teks; Sociocultural Practice, berhubungan dengan konteks seperti konteks situasi, lebih luas adalah konteks dan praktik insituasi dari media dalam hubungannya dengan masyarakat atau budaya politik tertentu. Pendekatan Fairclough juga berusaha menyatukan tiga tradisi, yaitu: analisis tekstual yang terinci di bidang linguistik; analisis makro-sosiologis praktis sosial; tradisi interoretatif dan mikro-sosiologis dalam sosiologi.

Penelitian ini akan menggunakan tiga level pandangan kritis Fairclough tersebut untuk mengetahui bagaimana Tirto.id menyusun informasi pada laporan mendalam berjudul "Kisah Korban Perkosaan yang Tak Akan Diindahkan Polisi”.

\section{METODE PENELITIAN}

Kajian tentang kasus penyintas kekerasan seksual dalam laporan mendalam berjudul "Kisah Korban Perkosaan yang Tak Akan Diindahkan Polisi" ini akan menggunakan pendekatan kualitatif. Penelitian kualitatif menurut Kirk dan Miller dalam Moleong (2006), adalah suatu tradisi tertentu dalam ilmu pengetahuan sosial yang secara fundamental bergantung dari pengamatan pada manusia baik dalam kawasannya maupun dalam peristilahannya.

Tahapan-tahapan dalam penelitian dilakukan beralas pemikiran kritis Norman Fairclough yang terdiri dari tiga tahap, yaitu deskripsi, interpretasi, dan eksplanasi (Fairclough, 1989). Pada tahap deskripsi kajian meliputi aspek leksikal dan gramatikal yang tercakup pada aspek makna eksperensial (idesional), 
interpersonal, serta makna tekstual teks, dan aspek struktur teks pada analisis genre.

Pada tahap interpretasi analisis dilakukan dengan mengkaji hubungan antara teks dan interaksi dalam teks. Tahap ini meliputi faktor sosial (interpretasi konteks) dari suatu teks. Sedangkan tahap eksplanasi berkaitan dengan hubungan antara konteks interaksi dan sosial.

Analisis dalam penelitian ini menggunakan pendekatan induktif dengan mengacu pada landasan teori. Landasan teori digunakan sebagai pedoman dalam melakukan pembahasan hasil penelitian. Penelitian ini berfokus pada media massa dan menggunakan paradigma kritis. Pemilihan paradigma kritis berkaitan dengan kesadaran bahwa teks atau wacana dalam media massa mempunyai pengaruh pada manusia (Littlejohn, 2002). Teks atau wacana dapat dimanfaatkan untuk tujuan tertentu, seperti menanamkan ideologi atau menyebarkan kepentingan media.

Paradigma kritis percaya bahwa realitas yang ada dalam media adalah realitas semu. Realitas ini dibangun atas kontruksi kekuatan sosial dan politik. Paradigma kritis mempunyai ciri tujuan penelitian untuk mengubah dunia yang tidak seimbang. Titik perhatian paradigma kritis terletak pada realitas yang dijembatani oleh nilai-nilai tertentu. Dilihat dari fokus penelitian ini, dapat dikatakan bahwa menurut paradigma kritis, media memiliki ideologi dan nilai-nilai tertentu yang memungkinkan adanya keberpihakan media. Dalam penelitian ini, peneliti berasumsi bahwa Tirto.id berpihak pada para penyintas kekerasan seksual dilihat dari dominasi pernyataan yang dicantumkan pada laporan, sehingga pelaku tindak kekerasan seksual menjadi pihak yang termarjinalkan.

\section{HASIL DAN PEMBAHASAN}

Berdasarkan jenisnya, teks yang akan diteliti merupakan wacana naratif. Wacana naratif, merupakan bentuk wacana yang menceritakan proses kejadian suatu peristiwa (Darma, 2014). Wacana naratif bertujuan untuk memberikan informasi yang sedetil-detilnya akan suatu rentetan peristiwa (kronologi). Objek dalam penelitian ini berupa laporan mendalam (in-depth reporting) berjudul "Kisah Korban Perkosaan yang Tak Akan Diindahkan Polisi”. Berita ditulis sebagai konstruksi wartawan melalui narasi (kisah) berdasarkan hasil wawancara dan paparan beberapa narasumber.

Pada bagian judul, Tirto.id memilih kalimat "Kisah Korban Perkosaan yang Tak Akan Diindahkan Polisi”. Penggunaan diksi "diindahkan", bermakna dipedulikan. Sebagai pembuka berita, Tirto.id sudah memperlihatkan pandangan pesimismenya pada institusi Polisi yang dianggap tak akan mengindahkan kisah korban perkosaan. Satu hal yang menarik perhatian pembaca, karena kontradiktif dengan value atau nilai yang seharusnya diemban oleh kepolisian sebagai pelindung rakyat, termasuk korban perkosaan.

Paragraf pertama kalimat pertama, Tirto.id menulis:

"Tak terlihat secuil pun rasa gentar, malu, atau duka di wajah Helga ketika ia mengisi acara malam dana untuk mendukung karya penyintas kekerasan seksual pada 11 November 2017 di Kantor Dagang Serikat Islam, Jakarta Pusat." Tirto.id menggunakan diksi atau pilihan kata berikut: (1) gentar, (2) malu, (3) duka yang menggambarkan kondisi narasumber saat itu.

Di laman KBBI Online, kata gentar, takut: ia tidak -- melihat musuh. Malu, 
merasa sangat tidak enak hati (hina, rendah, dan sebagainya) karena berbuat sesuatu yang kurang baik (kurang benar, berbeda dengan kebiasaan, mempunyai cacat atau kekurangan, dan sebagainya): ia -- karena kedapatan sedang mencuri uang; aku -- menemui tamu karena belum mandi; segan melakukan sesuatu karena ada rasa hormat, agak takut, dan sebagainya: murid yang merasa bersalah itu -- menemui gurunya; tidak usah -- untuk menanyakan masalah itu kepada ulama; kurang senang (rendah, hina, dan sebagainya): ia berasa -berada di tengah-tengah orang penting itu; -- bertanya sesat di jalan (-- berdayung perahu hanyut. Duka, adalah susah hati; sedih hati: kawan dalam suka dan --.

Ketiga kosakata tersebut diasosiasikan dengan perasaan dan kondisi emosional korban kekerasaan seksual. Pemilihan ketiga diksi tersebut digunakan untuk menunjukkan bahwa narasumber (Helga) telah bangkit dari keterpurukannya sebagai korban kekerasan seksual. Tirto.id kemudian menyematkan kosakata 'penyintas' pada kalimat yang sama untuk menunjukkan keberhasilan Helga melawan rasa trauma.

Kata penyintas menurut KBBI berarti orang yang mampu bertahan hidup. Sedangkan kata "korban" menurut KBBI berarti orang, binatang, dan sebagainya yang menderita (mati dan sebagainya) akibat suatu kejadian, perbuatan jahat, dan sebagainya. Dua diksi: 'penyintas' dan 'korban' digunakan Tirto.id untuk menegaskan penggunaan diksi-diksi sebelumnya. Bahwa narasumber, merupakan korban yang saat ini berhasil bertahan hidup walau telah mengalami perkosaan.

Pada paragraf tiga sampai lima berita berisikan kronologi peristiwa kekerasan seksual yang dialami Helga. Pada paragraf tiga kalimat keempat, Tirto.id menggunakan kalimat berikut:

"...tetapi sang ibu tak bereaksi keras terhadap si pelaku.”

Kata "keras" yang ditambahkan setelah kata "bereaksi" menunjukkan bahwa Tirto.id berpendapat reaksi ibu Helga bukanlah respon yang ideal, sesuai harapan. Kata bereaksi seharusnya dapat berdiri sendiri tanpa memerlukan kata bantu lain, tetapi Tirto.id menambahkan kata 'keras' untuk menunjukkan betapa minimnya reaksi ibu Helga terhadap tragedi yang dialami anaknya.

Pada paragraf tujuh kalimat ketiga, Tirto.id menggunakan kalimat:

"Alih-alih merasa ada yang salah dengan hubungan ini, Helga malah berpikir sikap posesif itu adalah bentuk kasih sayang."

Penggunaan pemarkah adversatif yaitu "alih-alih" dan "malah" menunjukkan ketidaksetujuan Tirto.id terhadap sikap narasumber. Pemilihan kosakata tersebut digunakan pada kalimat yang menceritakan masa lalu narasumber yang menunjukkan upaya Tirto.id, untuk menginformasi pembaca bahwa hal tersebut bukanlah sikap yang tepat untuk dilakukan.

Kalimat kutipan langsung pada paragraf delapan yang berbunyi:

"Kejadian dipaksa berhubungan sama mantan pacar enggak saya ceritakan ke siapa-siapa karena saya takut disalahkan,"

Dilanjutkan dengan kalimat:

“...yang saat itu masih buta soal isu kekerasan terhadap perempuan dalam pacaran"

menunjukkan penuturan narasumber tentang kekerasan terhadap perempuan saat berpacaran. Hal itu juga ditegaskan dengan penggunaan kata "masih buta". Tirto.id memilih untuk mengutip ucapan 
narasumber dalam bentuk kutipan langsung untuk mengedukasi pembaca. Sistem sosial masyarakat Indonesia masih memiliki kecenderungan menyalahkan perempuan sebagai korban kekerasan (victim-blaming) dan hal tersebut berdampak pada korban.

Di paragraf sepuluh sampai lima belas, ditemukan bahwa Tirto.id menyuguhkan teks yang secara langsung menunjukkan bagaimana korban kekerasan seksual mengalami trauma. Pada paragraf tiga belas, Tirto.id tidak secara eksplisit menyebutkan bentuk trauma yang dialami, tetapi memberi ide kepada pembaca melalui teks mengenai bagaimana seorang korban kekerasan seksual harus menghadapi dirinya sendiri paska mendapat kekerasan.

Pada subjudul "Titik Balik Menjadi Pendamping Penyintas" ditemukan bahwa Tirto.id menyajikan kutipan langsung dari dua narasumber dan memperluas informasi yang didapat untuk diteruskan kepada pembaca. Di paragraf 21, Tirto.id menuliskan opini yang mengacu pada judul:

"Helga dan sejumlah penyintas masih harus melewati perjalanan panjang dan sunyi dalam menghapus kekerasan seksual di negeri ini. Perkaranya, yang dilawan bukan hanya pelaku, bukan hanya aksi penegak hukum yang kerap jadi kendala untuk advokasi mereka."

Paragraf ini merupakan opini wartawan, karena tidak ada bukti yang mendukung bahwa kalimat yang disajikan berupa fakta yang ada di lapangan. Opini Tirto.id dapat digunakan sebagai indikator ideologi media yang dianutnya. Di sinilah media memiliki peran mengonstruksi realita sesuai ideologinya.

Di paragraf 27 kalimat terakhir, Tirto.id menggunakan pilihan kalimat: “...perilaku kasar bahkan kejam.” Penggunaan kata "kejam" ditujukan untuk menggambarkan bahwa sikap pelaku kekerasan kepada narasumber (Nanda) tidak menunjukkan belas kasihan. Sebenarnya penggunaan kata (1) kasar dan (2) kejam bisa dikategorikan sebagai pleonasme. Pleonasme adalah gaya bahasa dengan menggunakan kata-kata secara berlebihan dan ketika kata-kata tersebut dihilangkan, arti atau maknanya tidak berubah. Pada kalimat tersebut di atas, untuk tujuan memberi informasi pada pembaca mengenai perilaku pelaku, media cukup menggunakan diksi kedua saja.

Pada paragraf 32 kalimat terakhir, ditemukan penggunaan tanda kutip pada frasa "perbuatan asusila". Penggunaan tanda kutip seharusnya tidak perlu karena menimbulkan persepsi ganda. Padahal tanpa tanda kutip pun, frasa "perbuatan asusila" cukup jelas makna denotatifnya.

Pada paragraf 40 Tirto.id menunjukkan sikap memberi apresiasi positif pada keputusan yang diambil narasumber di masa lalunya. Hal ini terlihat dari penggunaan kalimat:

“...dan sejak itulah ia memutuskan secara tegas meninggalkan Rizki.” Pemilihan kata "tegas" pada kalimat tersebut memberi penekanan yang memiliki makna bahwa narasumber (Nanda) sudah mengambil keputusan terakhir tanpa ragu-ragu.

Di paragraf 45 kalimat pertama, Tirto.id menggunakan kata "menggerayangi". Walaupun kata tersebut merupakan bentuk kata dari kalimat aktif sehingga menyertakan subjek (dalam hal ini pelaku kekerasan seksual), tetapi pemilihan kata "menggerayangi" terkesan merendahkan korban karena memiliki makna peyoratif.

Di paragraf 58, Tirto.id menuliskan "Beberapa kali Anya mencoba cerita 
kepada teman-teman dekatnya, tetapi, menurut mereka, ia juga berperan atas peristiwa itu." Kalimat tersebut jika dimaknai secara kontekstual Tirto.id ingin mengedukasi pembacanya bahwa masyarakat memang cenderung menyalahkan korban kekerasan seksual. Penekanan informasi serupa sejauh ini sudah dua kali ditemukan dalam teks, di paragraf delapan dan paragraf 58.

Seperti yang ditemukan pada paragraf 21, di paragraf 62 Tirto.id kembali menggunakan pemilihan kalimat yang mengacu pada judul. Hal ini dapat dilihat dari kalimat berikut:

"Bila ia melapor ke polisi, yang menilai perkosaan harus ada unsur "paksaan", sangat mungkin Anya hanya jadi bahan omongan miring oleh polisi. Tak akan ada bukti kuat. Tak ada."

Frasa "bahan omongan miring" menunjukkan bahwa Tirto.id tidak percaya pada institusi kepolisian dalam menangani korban kekerasan seksual. Pemberian tanda kutip di antara kata "paksaan" menunjukkan adanya makna lain dari kata tersebut. Padahal jika diteliti, kata "paksaan" sudah menunjukkan makna yang tepat sesuai dengan konteks. Maka dapat disimpulkan bahwa penyematan tanda kutip merupakan bentuk penegasan pada kata tersebut. Pengulangan frasa "tak ada" yang dicetak tebal dan miring di akhir kalimat menunjukkan penegasan, bahwa sulit bagi korban kekerasan dalam pacaran untuk membuktikan dirinya sebagai korban perkosaan karena dianggap tidak ada unsur paksaan.

Setelah melakukan analisis tekstual pada teks, peneliti menemukan bahwa Tirto.id memiliki keberpihakan pada korban dan penyintas kekerasan seksual. Dalam laporan mendalam Tirto.id, ketiga narasumber merupakan perempuan korban kekerasan seksual dalam pacaran. Peneliti menemukan bahwa sepanjang laporan tersebut, Tirto.id mengkonstruksi informasi narasumber dari sudut pandang pihak perempuan. Para pelaku kekerasan seksual yang diceritakan kembali oleh narasumber semuanya laki-laki. Setelah melakukan analisis, ditemukan bahwa dari segi leksikal dan gramatikal, Tirto.id menulis dengan kalimat aktif sehingga selalu menyertakan pelaku. Penggunaan kalimat aktif dianggap menguntungkan korban karena tidak menghilangkan aktor dalam kekerasan terhadap perempuan.

Teks atau wacana yang diteliti memiliki genre laporan mendalam. Ini sesuai dengan rubrik di mana wacana ini berada, yaitu rubrik In Depth. Topik yang diangkat dalam laporan mendalam Tirto.id berkaitan dengan praktik sosial yang ada di masyarakat, yaitu mengenai korban kekerasan seksual. Secara intertekstual, laporan ini dibuat setelah adanya pernyataan kontroversial dari Kapolri Jenderal Tito Karnavian perihal pertanyaan dalam BAP yang diajukan saat melakukan penyidikan terhadap korban perkosaan. Ini terlihat dari judul yang tertera yang dapat dimaknai bahwa polisi mengabaikan cerita dari sisi korban pemerkosaan dan cenderung abai serta tidak sensitif terhadap psikologis dan emosional korban.

Peneliti juga menemukan teks laporan ini sebagai fungsi kritik dari media kepada masyarakat dan media lain. Kritik ini ditemukan pada awal paragraf dua:

"Berbeda dari mayoritas potret penyintas yang termuat pelbagai media massa, Helga terbuka dan mau tampil sebagai penyintas kekerasan seksual di muka publik,"

Hal ini dapat dimaknai bahwa media massa pada umumnya menggambarkan penyintas kekerasan seksual sebagai 
pribadi yang tertutup dan enggan tampil di muka publik. Kritik sosial pada masyarakat juga ditemukan pada keseluruhan teks. Tirto.id berulang kali menekankan penegasan bahwa korban kekerasan seksual cenderung disalahkan dan dekat dengan label maupun stigma negatif di masyarakat. Penggunaan kalimat aktif dengan aktor yang tidak dihilangkan pada teks juga menjadi salah satu bentuk kritik yang dilakukan Tirto.id.

Tidak hanya itu, laporan ini juga ditujukan untuk mengkritisi institusi terkait yaitu pihak kepolisian dalam menangani penyidikan terhadap korban pemerkosaan. Sesuai analisis yang dilakukan peneliti, laporan ini menginformasikan kepada khalayak cerita-cerita dari pihak korban yang pada umumnya dihilangkan oleh media. Dengan adanya laporan ini, masyarakat, institusi terkait, dan media lain mendapat pandangan baru dalam mengulas peristiwa yang berhubungan dengan kekerasan seksual terhadap perempuan.

Keberpihakan Tirto.id terhadap perempuan korban kekerasan seksual dapat dipengaruhi oleh ideologi dan nilai-nilai yang dianut media maupun jurnalis penulis laporan. Pada akhir laporan mendalam tersebut, tertulis jelas bahwa reporter yang meliput dan menemui narasumber berjumlah dua orang perempuan, penulis laporan seorang perempuan, dan penyunting tulisan seorang laki-laki. Walaupun pada laporan mendalam tersebut pihak laki-laki diposisikan sebagai pihak yang termarjinalkan, tetapi penyunting menyetujui konstruksi realitas jurnalis dan menayangkan laporan sebagaimana adanya.

Dari tiga dimensi analisis wacana model Norman Fairclough, peneliti menemukan bahwa ideasional pada laporan ini merujuk pada representasi tertentu yang ditampilkan dalam teks. Dalam hal ini, ideasional membawa muatan ideologi tertentu. Dari hasil analisis laporan mendalam Tirto.id, peneliti menyetujui bahwa muatan ideologi yang ingin ditampilkan adalah pemberontakan terhadap ideologi patriarki yang berkembang di masyarakat Indonesia. Untuk mengetahui ideologi sebenarnya dan nilai-nilai yang dipercayai oleh media, diperlukan penelitian lebih lanjut yang mengharuskan peneliti untuk ikut serta ke dalam proses produksi penulisan laporan mendalam Tirto.id.

Pada dimensi relasi, analisis merujuk pada bagaimana konstruksi hubungan antara jurnalis dengan pembaca. Tirto.id memiliki gaya penulisan dan rubrik-rubrik yang khas, sehingga pembaca Tirto.id sudah familiar dengan angle atau sudut pandang yang diambil dalam penulisan berita. Dalam laporan ini, teks disampaikan secara informal kepada pembaca, terlihat dari penggunaan kata-kata slang yang cukup banyak secara terbuka.

Sedangkan pada dimensi identitas, tampak di akhir laporan bahwa identitas jurnalis yang terkait dengan laporan mendalam ini disebutkan secara gamblang. Identitas berupa nama dan tugas kerja dituliskan sehingga pembaca dapat mengetahui kepedulian wartawan pada isu tertentu.

\section{PENUTUP}

\section{Simpulan dan Saran}

Setelah melakukan pembacaan wacana dengan menggunakan model analisis wacana kritis Norman Fairclough pada laporan mendalam Tirto.id berjudul "Kisah Korban Perkosaan yang Tak Akan 
Diindahkan Polisi" peneliti mengambil beberapa kesimpulan.

Dari level teks, khususnya pada tataran intertekstual, laporan ini dibuat sebagai reaksi atas pernyataan kontroversial Kapolri Jenderal Tito Karnavian yang diungkapkan pada BBC Indonesia pada Kamis 19 Oktober 2017 mengenai pertanyaan BAP dalam proses penyidikan terhadap korban pemerkosaan.

Secara tekstual, baik dari aspek leksikal maupun gramatikal, Tirto.id secara sengaja memilih kosakata yang bernuansa suportif terhadap korban dan penyintas kekerasan seksual. Yaitu dengan penggunaan pilihan kata semacam "tegas". Tirto.id juga memilih kosakata yang berkonotasi negatif seperti "bereaksi keras" dan "perilaku kasar bahkan kejam" ketika merujuk pada pelaku tindak kekerasan seksual. Penggunaan kalimat aktif menunjukkan Tirto.id tidak mengeluarkan aktor kekerasan seksual dari teks. Laporan mendalam Tirto.id memiliki fungsi kritik terhadap khalayak, tidak hanya terhadap masyarakat tetapi juga kritik terhadap institusi terkait yaitu kepolisian dan media massa dalam memberitakan kasus yang berkaitan dengan korban kekerasan seksual terhadap perempuan. Kritik ini sesuai dengan konteks sosial budaya (sociocultural practice) di Indonesia yang masih patriarkis. Melalui laporannya, Tirto.id melakukan perlawanan dengan mendobrak tataran ideal masyarakat pada berita terkait kekerasan seksual terhadap perempuan.

Menarik untuk membaca laporan ini dengan menggunakan pendekatanpendekatan yang berbeda semisal analisis naratif. Hal ini dapat memberi sudut pandang yang dapat melengkapi pembacaan berita. Penelitian serupa juga dapat dilakukan dengan menggunakan dua objek media yang berbeda untuk topik yang sama.

\section{DAFTAR PUSTAKA}

Darma, Yoce Aliah. 2014. Analisis Wacana Kritis dalam Multiperspektif. Bandung: PT Refika Aditama.

Ellyawati, Hetty Catur. 2011. Analisis

Wacana Kritis Teks Berita Kasus

Terbongkarnya Perlakuan Istimewa terhadap Terpidana Suap Arthalyta Suryani pada Media Online. Jurnal The Messenger Volume III Nomor 1 Edisi Juli 2011.

Eriyanto. 2001. Analisis Wacana: Pengantar Analisis Teks Media. Yogyakarta: LKiS.

Fairclough, Norman. 1989. Language and Power. London: Longman.

Kirnandita, Patresia. 24 November 2017. Kisah Korban Perkosaan yang Tak akan Diindahkan Polisi. Tirto. https://tirto.id/kisah-korbanperkosaan-yang-tak-akandiindahkan-polisi-cAzd diakses tanggal 27 Juni 2018

Kusumaningrat, Hikmat dan Kusumaningrat, Purnama. 2007. Jurnalistik: Teori \& Praktik. Bandung: PT Remaja Rosdakarya.

Littlejohn, Stephen W. 2002. Theories of Human Communication. Boston: Wadsworth.

Maghvira, Genta. 2017. Analisis Wacana Kritis pada Pemberitaan Tempo.co tentang Kematian Taruna STIP Jakarta. Jurnal The Messenger Volume 9 Nomor 2 Edisi Juli 2017. Moleong, Lexy J. 2006. Metodologi Penelitian Kualitatif. Bandung: PT Remaja Rosdakarya. 
Putri, R. Diantina. 24 November 2017. BAP Polisi: 'Apakah Saudari Menikmati Berhubungan Seks atau Tidak?'. Tirto. https://tirto.id/bappolisi-039apakah-saudarimenikmati-berhubungan-seks-atautidak039-cAy8 diakses tanggal 27 Juni 2018

Setiawan, Budi Yuliyanto. 2011. Analisis Wacana Kritis Pemberitaan Kekerasan Berbasis Gender di Surat Kabar Harian Merdeka. Jurnal Ilmiah Komunikasi MAKNA Vol. 2 No. 1 Pebruari 2011.

Setiyaningsih, Lian Agustina., \& Jatmikowati, Sri hartini. 2019. Media Baru Dalam Komodifikasi Waktu Luang Ibu Rumah Tangga. ETTISAL Journal of Communication Vol. 4 No. 1 Juni
$2019 . \quad$ Diakses dari https://ejournal.unida.gontor.ac.id/in dex.php/ettisal/article/view/3069/pdf $27 . \quad$ doi 10.21111/ettisal.v4i1.3069.

19 Oktober 2017. Tito Karnavian: Korban perkosaan bisa ditanya oleh penyidik 'apakah nyaman' selama perkosaan?. BBC Indonesia. http://www.bbc.com/indonesia/indo nesia-41676366 diakses tanggal 28 Juni 2018.

2018. Catatan Tahunan Kekerasan Terhadap Perempuan 2017. Komnas Perempuan.

https://www.komnasperempuan.go.i d/read-news-catatan-tahunankekerasan-terhadap-perempuan2018 diakses tanggal 28 Juni 2018 